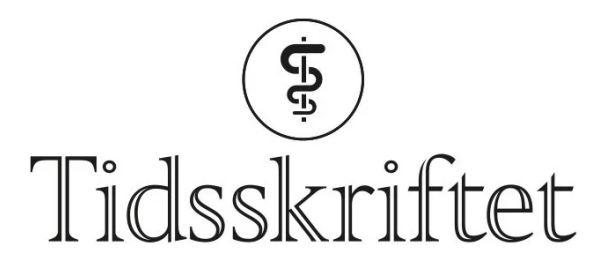

DEN NORSKE LEGEFORENING

\title{
Subakutt tyreoiditt etter covid-19
}

\author{
KORT KASUISTIKK \\ EIRIK TJØNNFJORD \\ eirik.tjonnfjord@so-hf.no \\ Tromboseklinikken \\ Sykehuset $\emptyset$ stfold Kalnes \\ og \\ Avdeling for blodsykdommer \\ Oslo universitetssykehus \\ og \\ Institutt for klinisk medisin \\ Universitet i Oslo \\ Eirik Tjønnfjord er konstituert overlege i blodsykdommer. \\ Forfatteren har fylt ut ICMJE-skjemaet og oppgir ingen interessekonflikter.
}

\section{RAGNAR BEKKHUS MOE}

Endokrinologisk avdeling Sykehuset Østfold Kalnes

Ragnar Bekkhus Moe er overlege.

Forfatteren har fylt ut ICMJE-skjemaet og oppgir ingen interessekonflikter.

\section{WALEED GHANIMA}

Sykehuset Østfold Kalnes

og

Avdeling for blodsykdommer

Oslo universitetssykehus

og

Institutt for klinisk medisin

Universitet i Oslo

Waleed Ghanima er ph.d., forskningssjef og professor.

Forfatteren har fylt ut ICMJE-skjemaet og oppgir ingen interessekonflikter.

\section{SAAD ABALLI}

Infeksjonsmedisinsk avdeling

Sykehuset Østfold Kalnes

Saad Aballi er overlege og har vært hovedansvarlig for covid-19-pasienter ved sykehuset.

Forfatteren har fylt ut ICMJE-skjemaet og oppgir ingen interessekonflikter.

\section{Vår kunnskap om akutte komplikasjoner ved covid-19 har etterhvert blitt god, men vi vet mindre om eventuelle følgetilstander. Med denne kasuistikken ønsker vi å gjøre}




\section{oppmerksom på subakutt tyreoiditt som en mulig komplikasjon til covid-19-infeksjon.}

En tidligere frisk mann i 40-årene som ikke brukte faste medikamenter fikk påvist SARS$\mathrm{CoV}-2$ ved polymerasekjederaksjon (PCR) i nasofarynks prøve. Infeksjonen forårsaket milde symptomer med feber og hoste i noen dager og krevde ingen spesifikk behandling. Han var deretter i god allmenntilstand i cirka tre uker, før han gradvis utviklet nedsatt allmenntilstand med feber $\left(38,3^{\circ} \mathrm{C}\right)$, dysfagi, hodepine, lett tørrhoste, dyspne og generell myalgi. Han hadde kun kortvarig febernedsettende effekt av Paracet og Ibux. Ved legevakt ble det påvist forhøyet CRP (C-reaktivt protein) på $88 \mathrm{mg} / \mathrm{L}$ (referanseområde < 5). Ny Covid-19-test var negativ. Han ble innlagt på sykehus for vurdering knappe seks uker etter første positive SARS-CoV-2-prøve.

I mottak var pasienten respiratorisk upåvirket, men subfebril og allment redusert. Han hadde regelmessig pulsfrekvens $95 \mathrm{slag} / \mathrm{min}$, blodtrykk $12 \mathrm{O} / 8 \mathrm{o} \mathrm{mmHg}$, temperatur $37,7^{\circ} \mathrm{C}$, respirasjonsfrekvens $18 / \mathrm{min}$ og saturasjon $95 \%$. Det ble notert diffus palpasjonsømhet på begge sider av halsen. Tyreoidea ble ikke funnet forstørret. Klinisk undersøkelse var ellers uten anmerkning, inkludert normale funn i svelget og ingen ømhet over tinningen. Blodprøver viste senkningsreaksjon $92 \mathrm{~mm}(<10)$, CRP $86(<6) \mathrm{mg} / \mathrm{L}$, leukocytter 11,9 × 109/L (3,5-11), øvrig var det upåfallende elektrolytter, nyrefunksjon, leverprøver, D-dimer, ferritin og prokalsitonin.

Under observasjon de første tre dagene på sengepost utviklet han residiverende feber der høyeste målte temperatur var $38,9^{\circ} \mathrm{C}$. Øvrig klaget han over halssmerte og myalgier. Han hadde vedvarende lett forhøyet pulsfrekvens (90-100/min), respirasjonsfrekvensen var normal og perifer oksygenmetning $\left(\mathrm{SpO}_{2}\right)$ var $95-98 \%$ uten tilførsel av oksygen.

Alle mikrobiologiske undersøkelser var negative. Dette inkluderte ny PCR-undersøkelse for covid-19, øvrig luftveispanel samt blodkulturer. Serologisk forelå det tegn til gjennomgått både Ebstein-Barr- og cytomegalovirusinfeksjon. Hepatitt B- og C-serologi var negativ. Det var normal røntgen toraks, og CT bihuler var negativ.

I løpet av andre døgn av innleggelsen ble det reist klinisk mistanke om subakutt tyreoiditt og stoffskifteprøver ble rekvirert. Disse viste tyreoideastimulerende hormon (TSH) o,o1 mIU/L (o,35-3,6), FT4 (tetraiodotyronin) 27,8 pmol/L (9-19), FT3 (triiodthyronin) $7,5 \mathrm{pmol} / \mathrm{L}(2,6-5,7)$, tyreoperoksydase $(\mathrm{P}-\mathrm{TPO})<3(<6)$ og TSH-reseptor-antistoff $(\mathrm{TRAS})<$ $0,9(<1,8)$. Biokjemisk var funnet forenlig med mild hypertyreose uten holdepunkter for autoimmun tyreoiditt ettersom TPO og TRAS var negative. Supplerende ultralyd av hals viste en generelt lett forstørret glandula thyreoidea med diskret omliggende ødem med heterogent parenkym, forenelig med tyreoiditt. Det var ingen holdepunkter for abscess i tyreoidea.

Ultralydfunnet var forenlig med tyreoiditt, men det ble beskrevet områder med lett hyperemi. Ved subakutt tyreoiditt er det normalt lav- til normal vaskularitet i kjertelen. På bakgrunn av dette og vedvarende symptomer i form av feber, myalgi og halssmerter samt forhøyet CRP og senkningsreaksjon vurderte man også andre diagnoser som temporalarteritt og polymyalgia revmatika. Hans unge alder under 50 år gjorde at man anså disse som mindre aktuelle, og startet behandling mot subakutt tyreoiditt (1). Han hadde hatt liten til ingen effekt av ikke-steroide antiinflammatoriske midler benyttet i flere uker før innleggelse, og det ble derfor valgt å starte med prednisolon peroralt i relativt moderat dose $20 \mathrm{mg} \times 1(\underline{2})$. Typisk forventes respons på behandling med glukokortikoider etter ett til tre døgn. Hos pasienten tilkom betraktelig bedring på dag to etter oppstart, CRP falt fra 92 til $35 \mathrm{mg} / \mathrm{L}$. I epikrise ble det ble skissert detaljert nedtrappingsplan av prednisolon over en måned.

Ved klinisk kontroll to måneder senere var pasienten symptomfri, og hadde normale tyreoidea- og infeksjonsprøver. Han var uten medikamentell behandling og i god allmenntilstand. Man anbefalte videre kontroll hos fastlege med kontroll av 
tyreoideaprøvene hver fjerde uke i minimum fire måneder. Det ble ikke ansett som nødvendig å gjøre ny ultralyd av tyreoidea.

\section{Diskusjon}

Vi ønsker med denne kasuistikken å gjøre oppmerksom på at subakutt tyreoiditt kan være en komplikasjon og oppstå i forløpet eller etterkant av en covid-19-infeksjon. Det er ikke mulig å påvise noen sikker årsakssammenheng mellom covid-19 og subakutt tyreoiditt hos denne pasienten, men vi anser det som sannsynlig.

Subakutt tyreoiditt er antatt forårsaket av en viral infeksjon eller som ledd i en postviral inflammatorisk prosess. Ofte har det vært symptomer på øvre luftveisinfeksjon to til åtte uker i forveien. Klynger av tilfeller har vært rapportert i assosiasjon med coxsackievirus, adenovirus og andre virale infeksjoner (3,4.). Tilstanden oppfattes ikke som knyttet til autoimmun inflammasjon, men det er funnet en sterk assosiasjon til HLA-B35 i flere etniske grupper $(3,4$.$) . Man antar at tilstanden oppstår etter virusinfeksjon som skaper et antigen,$ enten av viral opprinnelse eller som følge av vevsskade som følge av virusinfeksjonen, som bindes til HLA-B35 på makrofager (5, 6 ). Antigen-HLA-B35 komplekset aktiverer cytotoksiske T-lymfocytter som angriper follikelcellene i tyreoidea fordi disse har strukturell likhet med antigenet (7.). Inflammasjonsprosessen i tyreoidea medfører utslipp av ferdig lagret tyroideahormon og fører til hypertyreose.

Subakutte tyreoiditter kan følge et typisk forløp med initial hypertyreose, kortvarig eutyreose og avslutningsvis hypotyreose før restitusjon og normalt stoffskifte (르). Hver fase varer typisk i to til åtte uker, men det er store variasjoner. Den hypertyreote fasen varer til lagrene av tyreoideahormon er tømt. Ettersom inflammasjonen i tyreoidea dempes vil etterhvert follikelcellene restitueres og igjen produsere tyroksin. I tiden det tar før full restitusjon av follikelcellene kan det være behov for tyroksin-erstattende behandling. Etter restitusjon forventes full normalisering av tyreoidea-funksjonen og eventuell subtitusjonsbehandling kan trappes ned og seponeres.

Ut fra det vi vet er dette den første kasuistikken med subakutt tyreoiditt etter covid-19infeksjon i Norge. Det er beskrevet flere kasuistikker internasjonalt med subakutt tyreoiditt etter covid-19-infeksjon ( $\underline{8-10})$. Diagnosen subakutt tyreoiditt ble vurdert som overveiende sannsynlig grunnet typisk sykehistorie, symptomer, funn ved blodprøver og supplerende ultralyd av tyreoidea. Som forventet var det også svært god klinisk effekt av behandling med glukokortikoid i moderat dose.

Det er rapportert at subakutt tyreoiditt kan oppstå både under og - i hovedsak - etter covid19-infeksjon $(\underline{8}, \underline{10})$. Studier har påvist at tyreoidea har angiotensinkonverterende enzym 2reseptorer (11), som også er funnet essensielt for at SARS-CoV-2 skal infisere humane celler (9.). Vi har ikke funnet litteratur som i detalj beskriver hvordan infeksjon med SARS-CoV-2 forårsaker T-cellemediert skade i tyreoidea, men det er nærliggende å tenke seg at patofysiologien ligner det som sees i forløpet av andre virale infeksjoner.

Med denne kunnskapen er det naturlig å tenke seg at vi vil kunne se flere tilfeller av subakutt tyreoiditt hos personer med eller gjennomgått covid-19. Det er derfor viktig å vurdere denne komplikasjonen når en som tidligere har fått påvist covid-19 utvikler tegn til symptomer på hypertyreose samt feber og/eller hals-/nakkesmerter. Subakutt tyreoiditt kan ha diffuse symptomer som potensielt $ø$ ker risiko for underdiagnostisering. Vi anbefaler liberal kontroll av tyreoideaprøver dersom man får nye symptomer etter initial bedring etter covid-19-infeksjon.

Pasienten har gitt samtykke til at artikkelen blir publisert.

Artikkelen er fagfellevurdert. 


\section{LITTERATUR}

1. Ross DS, Burch HB, Cooper DS et al. 2016 American Thyroid Association Guidelines for diagnis and management of hypertyroidism and other causes of thyrotoxicosis. Thyroid 2016; 26: 1343-421. [PubMed][CrossRef]

2. Benbassat CA, Olchovsky D, Tsvetov G et al. Subacute thyroiditis: clinical characteristics and treatment outcome in fifty-six consecutive patients diagnosed between 1999 and 2005. J Endocrinol Invest 2007; 30: 631-5. [PubMed][CrossRef]

3. de Bruin TW, Riekhoff FP, de Boer JJ. An outbreak of thyrotoxicosis due to atypical subacute thyroiditis. J Clin Endocrinol Metab 1990; 70:396-402. [PubMed][CrossRef]

4. Martino E, Buratti L, Bartalena L et al. High prevalence of subacute thyroiditis during summer season in Italy. J Endocrinol Invest 1987; 10:321-3. [PubMed][CrossRef]

5. Desailloud R, Hober D. Viruses and thyroiditis: an update. Virol J 2009; 6: 5. [PubMed][CrossRef]

6. Nyulassy S, Hnilica P, Buc M et al. Subacute (de Quervain's) thyroiditis: association with HLA-Bw35 antigen and abnormalities of the complement system, immunoglobulins and other serum proteins. J Clin Endocrinol Metab 1977; 45: 270-4. [PubMed][CrossRef]

7. Kojima M, Nakamura S, Oyama T et al. Cellular composition of subacute thyroiditis. an immunohistochemical study of six cases. Pathol Res Pract 2002; 198: 833-7. [PubMed][CrossRef]

8. Chong WH, Shkolnik B, Saha B et al. Subacute thyroiditis in the setting of coronavirus disease 2019. Am J Med Sci 2021;361: 400-2. [PubMed][CrossRef]

9. Muller I, Cannavaro D, Dazzi D et al. SARS-CoV-2-related atypical thyroiditis. Lancet Diabetes Endocrinol 2020; 8: 739-41. [PubMed][CrossRef]

10. Mattar SAM, Koh SJQ, Rama Chandran S et al. Subacute thyroiditis associated with COVID-19. BMJ Case Rep 2020; 13: e237336. [PubMed][CrossRef]

11. Rotondi M, Coperchini F, Ricci G et al. Detection of SARS-COV-2 receptor ACE-2 mRNA in thyroid cells: a clue for COVID-19-related subacute thyroiditis. J Endocrinol Invest 2021; 44: 1085-90. [PubMed] [CrossRef]

Publisert: 28. juni 2021. Tidsskr Nor Legeforen. DOI: 10.4045/tidsskr.21.0169

Mottatt 1.3.2021, første revisjon innsendt 13.3.2021, godkjent 30.5.2021.

Publisert under åpen tilgang CC BY-ND. Lastet ned fra tidsskriftet.no 26. april 2023. 